torian and scholar, died at his home on February 16, 1992, following a short illness.

Born in 1899 in Ferrum, the son of John Kemper and Lelia Angle Hurt, Frank B. Hurt began his formal education at Ferrum Training School, from which he graduated in the first graduating class of 1919 . He began his undergraduate education at Randolph-Macon College, and received his B.A. degree from Washington and Lee University in 1923. He received an M.A. degree (economics) from the University of Virginia, and a second M.A. degree (history) from Princeton University. Professor Hurt did doctoral studies at Johns Hopkins University and attended Harvard University during summer sessions.

In 1927 he returned to Ferrum Training School as an instructor. $\mathrm{He}$ received an appointment as an assistant professor of political science at Western Maryland College in 1930 , and in 1947 was promoted to associate professor and head of the Department of Political Science. He married Mary Ann Wescott of Nassawadox, Virginia in 1943. In 1965, after 35 years at Western Maryland College, Professor Hurt retired and was subsequently made Professor Emeritus of Western Maryland College. He and Mrs. Hurt returned to Ferrum to live on the Hurt family property. In 1965 he accepted an appointment as professor of history and head of the Division of Social Science at Ferrum College. When he retired from teaching at Ferrum College in 1970 he was made Professor Emeritus.

Throughout his professional career he was a member of many professional societies and associations and is listed in numerous publications including Who's Who in America. He was honored by Western Maryland College by being elected to the Western Maryland Sports Hall of Fame in recognition of his 35 years as volunteer tennis coach, by Ferrum College as a Distinguished Alumnus, and received the Benjamin Moore Beckham Medallion in 1978. In 1982, Professor Hurt received an honorary Doctor of Humanities Degree from Ferrum College in recognition of his service to education and his community. The Alumni Association commissioned a formal portrait of
Professor Hurt which was presented to the College in 1991. The Board of Trustees of Ferrum College commissioned him to write a history of the College, and in 1977 A History of Ferrum College-An Uncommon Challenge 1914-1974 was published as the first official history of the College. With the proceeds from the book, he and Mrs. Hurt established a student scholarship fund at Ferrum in memory of his parents. He published several other monographs dealing with the history of the foothills of the Blue Ridge and its people.

He was active in many civic affairs, including: past chairman of the Board of Directors of the First National Bank of Ferrum, active past president of the Franklin County Historical Society, member of the Lions Club of Ferrum, and the $\mathbf{5 0}$ Year Club of the Alumni Association of Ferrum College. He was a trustee of Ferrum College at the time of his death and a member and former trustee of St. James United Methodist Church of Ferrum.

\section{Joseph E. Kallenbach}

Joseph Kallenbach, professor emeritus of political science at the University of Michigan, died November 13, 1991 in Ann Arbor. He was 89 years old. He was born in Tuscumbia, Missouri, received his bachelor's degree from Central Missouri State College in 1926, his master's from the University of Missouri in 1928 and his Ph.D. from the University of Michigan in 1939. He taught in secondary schools and colleges in Missouri before coming to Michigan, where he became an instructor in 1939 and a professor in 1953.

Joe was known from the beginning at Michigan for his excellence in teaching, careful scholarship, and effective participation in administrative roles. In the late thirties and forties he was one of the stalwarts in the early development of political science at Michigan. He was a junior member of a small department of 10 to 12 men. Together with Arthur Bromage, Harold Dorr and James
Pollock he taught the basic courses in American Government and Constitutional Law. He was knowledgeable, well-organized, inspiring as a teacher. Those of us who worked with him admired his skills as well as the training he gave us. He monitored our performance very closely.

Joe's book on The American Chief Executive in 1966 was a pioneering classic, still referred to today. Subsequently, in 1983, with his wife Jessamine he published American State Governors, 1776-1976, a threevolume work. He wrote seminal articles on civil rights, the electoral college, and the role of the Supreme Court in the American system. He had a variety of other functions. He worked with the war Labor Board 1944-46, was a member of the American Arbitration Association, was a regular member of the panel of arbitrators after the war, acted as associate chairman of the department of political science, helped develop the University's residence hall system, was for many years secretary of the faculty of the college of Literature, Science and the Arts, and was faculty representative on the Board in control of Intercollegiate Athletics. He even ran for Ann Arbor City Council in 1965. Joe's diversity of interests and versatility in performance was admirable.

Although Joe was no "behaviorist" (and indeed probably would dislike such a label) he had a very inquisitive quantitative orientation to the study of politics. He delighted in precision, in collecting statistics, and in mobilizing his evidence carefully. As one colleague put it: "If Joe had come along a little later and absorbed newer methodologies, he might well have become a state of the art behavioral scientist." He was, however, very effective in his own scholarly world, using his own approaches.

To his colleagues, friends, and students, Joe was a man and scholar of great personal probity, loyalty, and integrity. He had a great impact on those close to him. Two of his former students who coauthored a textbook on the presidency (now in its third edition) dedicated their book "To Joseph E. Kallenbach, who pointed the way and from whom we both learned much." We all have 
learned from Joe Kallenbach and are grateful, while we mourn his passing.

Samuel J. Eldersveld

George Grassmuck

University of Michigan

\section{Betty Nesvold}

I am writing with a sense of sorrow and of personal loss, for Betty Nesvold has passed away.

By any measure, Betty Nesvold was remarkable. A mother of five, her life was intimately interwoven with San Diego State University. Two of her children graduated from here as did her husband Al. Betty was too busy raising her brood to focus on her own education, and it wasn't until she was in her early forties that she completed her degree in our department. She decided to join the work force, but was turned down by Ryan Corporation because she could not pass the physical-a trick knee did her in. She returned to San Diego State University for her master's degree, linking up with the Feierabends, who were beginning their path-breaking research on comparative political violence. Her master's thesis was so highly regarded in the discipline that although unpublished it was often cited in the literature. With family in tow, Betty moved on to the University of Minnesota, where she received her doctorate. In 1967, she returned to San Diego State University as an assistant professor. Within the next seven years, Betty became perhaps the most prominent woman in the American Political Science Association, becoming its first woman treasurer in 1974. Betty also served as president of the Western Political Science Association, where she was instrumental in shaking up the ol' boy network and revitalizing this regional association. In addition, Betty was the first woman to be chair of the Inter-University Consortium for Political Research, a founding member and president of the Woman's Caucus of the APSA, as well as founding and heading the Social Science Research and Instructional Council in the California State University system.

At San Diego State University, Betty chaired the Political Science
Department, served as associate dean for the College of Arts and Letters, and was for many years a member of the Woman's Studies Advisory Committee, a program which was close to her heart.

Betty Nesvold was a pioneer. Her early scholarship was on the cutting edge of the discipline; her more recent work on feminist concerns stretched the boundaries on sensitive social issues. She taught and lead by example. She broke down barriers and walked where women had never trod before. For the new generation of women political scientists who follow in her footsteps, there will always be an indebtedness; for Betty Nesvold made it possible.

Lou Terrell

San Diego State University

\section{Thomas C. Wiegele}

A funeral Mass was held Wednesday, August 14, for Thomas C. Wiegele, a well-known Northern Illinois University political science professor and Presidential Research Professor, several days before he planned to retire.

Wiegele, 58, died of an aneurysm just after noon Friday, August 9, at DeKalb's Kishwaukee Community Hospital, according to his son, Edward Wiegele.

Wiegele was considered a pioneer in biosocial research and in electronic voice stress analysis of political leaders during international crises. His research interests also included the impact of biomedical factors on political behavior and international biotechnology policy.

Last year, he received a $\$ 15,000$ grant from the U.S. Institute of Peace to research and write a book, "The Libyan Chemical Weapons Plant Episode." His research in electronically analyzing voice patterns of world leaders won him international attention when, in 1979, he traveled to Moscow to present a paper at the International Political Science Association, detailing his voice stress findings analysis of political leaders during the 1961 Berlin crisis.

His widow, Mary Wiegele, an NIU publications editor, said her husband, in his retirement, was "looking forward to studying photography and Spanish, and he planned to stay active in scholarship." A retirement party was held for him last Wednesday night, less than 48 hours before his death, by colleagues who gathered to honor him at NIU's Social Sciences Research Institute.

Wiegele was born August 18, 1932, in Milwaukee, the son of Joseph and Leone Kohn Wiegele. He served in the U.S. Army during the Korean conflict and received a bachelor's degree from Marquette University, Milwaukee, in 1956. He married Mary Preo in Milwaukee on November 17 the same year.

After college, Wiegele was a high school teacher in Brown Deer, Wisconsin. He later earned master's and $\mathrm{Ph} . \mathrm{D}$. degrees from the University of Pennsylvania, Philadelphia, in 1965 and 1967 , respectively.

Wiegele was a political science faculty member at St. Joseph's College, Philadelphia, 1967-69, and served as a research associate and administrative officer at Penn's Foreign Policy Research Institute, 1965-68. He joined NIU's political science department faculty in 1969.

Wiegele's books included Biopolitics: Search for a More Human Political Science (1979) and Biology and the Social Sciences: An Emerging Revolution (1982), both from Westview Press, Boulder, Colorado. He was a co-author of Leaders Under Stress: A Psychophysiological Analysis of International Crises with Gordon Hilton, Kent Oots and Susan Kisiel, and published by Duke University Press, Durham, North Carolina in 1985. Wiegele also was the author of many journal articles.

"He was a very important member of our faculty," said Lettie Wenner, chair of Northern's political science department. "It's a terrible loss to us. We were hoping that he'd be able to stay on as an emeritus professor and guide graduate students. His great contribution was the creation of our biopolitics program."

Wenner notes that Wiegele was one of the first to work in the new field of biosocial research. He was director of NIU's Program for Biosocial Research, and also was one of the founding members of the Association for Politics and the Life Sciences, an international society. Wiegele served as APLS executive 